\title{
Serotonergic Neurons Migrate Radially through the Neuroepithelium by Dynamin-Mediated Somal Translocation
}

\author{
Alicia L. Hawthorne, Christi J. Wylie, Lynn T. Landmesser, Evan S. Deneris, and Jerry Silver \\ Department of Neurosciences, Case Western Reserve University, Cleveland, Ohio 44106
}

\begin{abstract}
Embryonic CNS neurons can migrate from the ventricular zone to their final destination by radial glial-guided locomotion. Another less appreciated mechanism is somal translocation, where the young neuron maintains its primitive ventricular and pial processes, through which the cell body moves. A major problem in studying translocation has been the identification of neuronal-specific markers that appear in primitive, radially shaped cells. We used enhanced yellow fluorescent protein under control of the Pet-1 enhancer/promoter region (ePet-EYFP), a specific marker of early differentiated serotonergic neurons, to study their migration via immunohistology and time-lapse imaging of living slice cultures. As early as E10.0, ePet-EYFP-expressing neurons were axonless, radially oriented, and spanned the entire neuroepithelium. The soma translocated within the pial process toward the pial surface and could also translocate through its neurites, which sprouted from the pial process. The dynamin inhibitor dynasore significantly reduced translocation velocity, while the nonmuscle myosin II inhibitor blebbistatin and the kinesin inhibitor AMP-PNP had no significant effect. Here we show for the first time that serotonergic neurons migrate by somal translocation mediated, in part, by dynamin.
\end{abstract}

\section{Introduction}

Radial glial-guided locomotion is accepted as the mode of radial neuronal migration in the CNS (Rakic, 1971). Morest (1970) proposed that there is a different, autonomous mechanism of neuronal migration called somal translocation. Translocating neurons are themselves aligned radially, transiently maintaining their pial and ventricular endfeet (Morest, 1970; Watanabe et al., 1991; Morest and Silver, 2003). From the moment the neuron is born, it can span the neuroepithelium with processes inherited from its immediate progenitor cell (Miyata et al., 2001). Movement of the cell body occurs independently of radial glia by shifting the position of the soma through the pial process (Miyata et al., 2001; Morest and Silver, 2003). Somal translocation has been thought to occur within restricted regions and at early stages when the neuroepithelium is thin (Rakic, 1971; Honda et al., 2003).

Somal translocation was first examined in embryos using the Golgi technique (Morest, 1970) and electron microscopy (Hinds and Hinds, 1974). Using DiI placed at the pial surface or within axon bundles distant from the area of interest, retrogradely labeled neurons were found with endfeet at the limiting mem-

Received May 18, 2009; revised 0ct. 10, 2009; accepted Nov. 3, 2009.

This work was supported by National Institutes of Health/National Institute of Neurological Disorders and Stroke Grant NS25713 (J.S.) and National Institute of Health Grant R01MH62723 (E.SD). We thank Hongmei Hu, Cathy Doller, Maryanne Pendergast, Katie Krueger, and Roxanne Murphy for their technical assistance. We thank Heather Broihier, Yoshi Imanishi, David Katz, and Steve 0'Gorman for the generous use of their equipment. We also thank Warren Alilain and Sarah Busch for their helpful comments.

Correspondence should be addressed to Jerry Silver, Department of Neurosciences, Case Western Reserve University, 10900 Euclid Avenue, Cleveland, Ohio 44106. E-mail: jxs10@cwru.edu.

DOI:10.1523/JNEUROSCI.2333-09.2010

Copyright $\odot 2010$ the authors $\quad 0270-6474 / 10 / 300420-11 \$ 15.00 / 0$ branes (Brittis et al., 1995; Snow and Robson, 1995; Nadarajah et al., 2001). Fluorescent labeling of the neuroepithelium made time-lapse imaging possible (Miyata et al., 2001; Noctor et al., 2004; Borrell et al., 2006). Although these techniques were not neuronal-specific, they generated insights into the translocation phenomenon. The suggestion of long-distance translocating neurons in the late-stage ferret cortex contradicted the belief that translocation only occurred at early stages and over short distances (Borrell et al., 2006). Specifically labeled, translocating bipolar neurons were first visualized in the postnatal retina (Morgan et al., 2006). However, the initial, long-distance migration of the neuron was not examined. Thus, an ideal method of labeling to study translocation is an early onset genetic tag that can readily differentiate primitive neurons from radial glia, that remains stable as the cell matures and that can be visualized in living tissues.

While the anatomy of the serotonergic system has been well described (Levitt and Moore, 1978; Wallace and Lauder, 1983), serotonergic neuron migration from the ventricular zone to the raphe has not been examined due to a lack of early serotonergic neuron-specific markers. Serotonin is not expressed until after migration (Wallace and Lauder, 1983). However, an extremely early, temporally stable marker specific to serotonergic neurons is the ETS domain transcription factor Pet-1 (Hendricks et al., 1999; Pfaar et al., 2002). Pet-1, in combination with $N k \times 2.2$ and $L m x 1 b$, is necessary and sufficient to induce a serotonergic fate in neurons (Hendricks et al., 1999; Cheng et al., 2003; Ding et al., 2003). In transgenic mice with the Pet- 1 enhancer/promoter region driving enhanced yellow fluorescent protein (Scott et al., 2005a,b), serotonergic neurons are visible as radially shaped cells as early as embryonic day 10.0 (E10.0). Using immunohistology and slice culture time-lapse imaging, we demonstrate for the first 
time that serotonergic neurons migrate by somal translocation mediated, in part, by dynamin. We also characterized the potentially regulatory extracellular environment.

\section{Materials and Methods}

Transgenic mice. We bred ePet-EYFP-expressing mice in a mixed C57BL/6 and 129 background (Hendricks et al., 1999; Scott et al., 2005a,b). We identified E0.5 as 12:00 noon the day of the plug. We genotyped embryos either by PCR with primers 5 '-GAA CTC CAG CAG GAC CAT GT-3' and 5' -TAT ATC ATG GCC GAC AAG CA-3' or by a fluorescence dissecting microscope. Animals were treated in accordance with Case Western Reserve University IACUC regulations.

Histology. Timed pregnant females were killed, and embryos at E10.0, E10.5, E11.5, E12.5, and E13.5 were fixed by immersion in $4 \%(\mathrm{w} / \mathrm{v})$ paraformaldehyde for $1 \mathrm{~h}$. We cryoprotected embryos in 30\% (w/v) sucrose in phosphate buffered saline (PBS) overnight, froze them in Frozen Section Medium (Fisher) on dry ice, and cryosectioned them in coronal or sagittal $20 \mu \mathrm{m}$ sections. We dried sections onto Superfrost Plus slides (Fisher). We blocked the tissue for $2 \mathrm{~h}$ at room temperature or overnight at $4^{\circ} \mathrm{C}$ in $5 \%(\mathrm{v} / \mathrm{v})$ normal goat serum (Invtrogen), $0.1 \%(\mathrm{w} / \mathrm{v})$ bovine serum albumin (Sigma), with or without $0.1 \%(\mathrm{v} / \mathrm{v})$ Triton-X (Sigma) to permeabilize cells, in PBS. We incubated primary antibody in blocking serum overnight at $4^{\circ} \mathrm{C}$. We stained YFP with an antibody to GFP (rabbit; 1:500; Invitrogen). Extracellular marker antibodies were to laminin $A+B$ chains (rat IgG; 1:500; Millipore Bioscience Research Reagents), chondroitin sulfate proteoglycan (CS-56; mouse IgM; 1:500; Sigma), heparan sulfate proteoglycan (HSPG clone HepSS-1; mouse IgM; 1:200; Seikagaku, Associates of Cape Cod), fibronectin (rabbit; 1:400; Dako), CAT-301 (mouse IgG $\mathrm{Ig}_{1} ; 1: 500$; Millipore Bioscience Research Reagents), CAT315 (mouse IgM; 1:2000; Millipore Bioscience Research Reagents), CAT316 (mouse IgM; 1:7000; Millipore Bioscience Research Reagents), and tenascin (clone 578; rat IgM; 1:50; kind gift from A. Faissner, RuhrUniversity Bochum, Bochum, Germany). Antibodies to integrins contributing to the receptor complex for laminin were $\alpha 1, \alpha 2, \alpha 3$ and $\alpha 6$ (goat IgG; 1:50; Santa Cruz Biotechnology). We labeled neuroepithelial cells with an antibody to nestin (mouse $\operatorname{IgG}_{1} ; 1: 20$; Millipore Bioscience Research Reagents) and proliferating cells with Ki67 ( $\mathrm{msIgG}_{1 \mathrm{k}} ; 1: 500$; BD Pharmingen). Neuronal markers included antibodies to 5-HT (serotonin; rabbit; 1:10,000; Immunostar); TuJ1 (neuronal $\beta$-III tubulin; mouse $\mathrm{IgG}_{2 \mathrm{a}} ; 1: 500$; Millipore Bioscience Research Reagents); polysialic acidneuronal cell adhesion molecule (PSA-NCAM; mouse IgM; 1:200; Millipore Bioscience Research Reagents); tau (an axonal marker; rabbit; 1:100; Abcam); and microtubule associated protein 2 (MAP2 clone HM-2, a dendritic marker; mouse IgG $;$; 1:500; Sigma). We labeled radial glia with antibodies to glutamate aspartate transporter (GLAST; rabbit; 1:500; kind gift from M. Watanabe, Hokkaido University, Sapporo, Japan), brain lipid binding protein (BLBP; rabbit; 1:500; Millipore Bioscience Research Reagents), and RC2 (mouse IgM; 1:100; developed by M. Yamamoto, University of Tsukuba, Tsukuba, Japan, and obtained from the Developmental Studies Hybridoma Bank developed under the auspices of the National Institute of Child Health and Human Development and maintained by The University of Iowa, Department of Biological Sciences, Iowa City, IA). Mature glial markers included antibodies to vimentin (clone LN-6; mouse IgM; 1:200; Sigma) and glial fibrillary acidic protein (GFAP; clone G-A-5; mouse $\operatorname{IgG}_{1}$; 1:500; Sigma). After washing 3 times in PBS, we incubated tissue with the appropriate secondary antibody raised in goat or donkey (Alexa Fluor 488 or $594 ; 1: 500$; Invitrogen) overnight at $4^{\circ} \mathrm{C}$. Then, we washed tissue 3 times in PBS. We coverslipped slides using Citifluor (Ted Pella) mounting media. We obtained images from a Zeiss LSM 510 confocal microscope, and all images but RC2 at E10.5 were collapsed Z-stacks.

Slice culture. We dissected embryos in cooled and oxygenated mouse Tyrode's solution. We embedded embryos into $37^{\circ} \mathrm{C}$ Agarose, type IX, Ultra-low Gelling Temperature (7.33\% (w/v); Sigma) in Tyrode's. Then, we firmed the block at $-20^{\circ} \mathrm{C}$ for $4-5 \mathrm{~min}$. without freezing the embryo. We sliced either coronal or sagittal sections 200-250 $\mu \mathrm{m}$ thick using an Oscillating Tissue Slicer (Electron Microscopy Sciences). We used the rhombencephalic isthmus and pontine flexure as landmarks to target rostral raphe cells in the midbrain/hindbrain (Goridis and Rohrer, 2002). We plated slices onto Millicell CM organotypic filters (Millipore) in 50 mm glass-bottom dishes (WillCo Wells B.V.) with Neurobasal (Invitrogen) containing $0.072 \%(\mathrm{w} / \mathrm{v})$ HEPES (Sigma).

Time-lapse imaging. We visualized ePet-EYFP-expressing neurons after $2 \mathrm{~d}$ in vitro with fluorescence time-lapse microscopy. We obtained Z-stacks at $5 \mathrm{~min}$ intervals for $1-7 \mathrm{~h}$ on a Zeiss Axiovert $200 \mathrm{M}$ fluorescence microscope using a stage heated to $37^{\circ} \mathrm{C}$ and Axiovision software (Carl Zeiss). We then chose single images at each time-point for videos. We edited pictures in Adobe Photoshop and assembled them into videos with MetaMorph (Universal Imaging Corporation), with each image playing for $5 / 30 \mathrm{~s}$. We traced images from the time-lapse movies at time 0 min using Neurolucida software (MicroBrightField). Projected stacks for Figure 5 were created in ImageJ (Rasbald, NIH).

Inhibitor application. We used the following inhibitors: $80 \mu \mathrm{M}$ dynasore (dynamin 1 and 2 GTPase inhibitor; Tocris Bioscience) (Macia et al., 2006; Kolpak et al., 2009), $100 \mu \mathrm{M}$ blebbistatin (nonmuscle myosin II inhibitor; Sigma) (Schaar and McConnell, 2005), $1 \mathrm{~mm}$ adenosine $5^{\prime}$ ( $\beta, \gamma$-imido)triphosphate tetralithium salt hydrate (AMP-PNP, a kinesin inhibitor; Sigma) (Bananis et al., 2000) control, and vehicle control (dimethyl sulfoxide (DMSO); Sigma). We reconstituted the dynasore and blebbistatin with DMSO and AMP-PNP with sterile distilled water, then diluted them with Neurobasal plus HEPES and dextran Texas Red (3000 MW; Invitrogen) for injection visualization. After 25 min of time-lapse imaging, we injected $46 \mu \mathrm{l}$ of each inhibitor into the slice using a Nanoject II (Drummond). To the dish, we added $500 \mu$ lof double the concentration of inhibitor in Neurobasal plus HEPES without dextran Texas Red to prevent wash-out. Alternatively, blebbistatin was also applied directly to the top of the slice instead of being injected.

Quantification. To examine the coexpression of ePet-EYFP with neuronal and glial markers, we counted the number of ePet-EYFPexpressing cells at E10.5 that were positive or negative for the markers TuJ1, Tau, Map2 and RC2.

We calculated the average speed of translocation for each clearly translocating neuron by measuring in Axiovision the total distance the trailing end of the cell body had traveled and dividing by the amount of time. We traced the trailing end of cell bodies in Axiovision for Figure 5/supplemental Movie 1 (available at www.jneurosci.org as supplemental material), Figure 6, and Figure 8/supplemental Movie 3 (available at www. jneurosci.org as supplemental material), and the velocity of movement during each 5 min interval was calculated.

For inhibitors, we traced the neurons as above and computed the velocity for each $5 \mathrm{~min}$ period, taking into account an immobile reference point to subtract out slice movement as a result of the injection. Only cells within the spread of dextran Texas Red were included in the analysis. We found no significant difference between adding blebbistatin to the top of the slice and injecting it into the slice and so pooled the data into one blebbistatin group. We defined the time before the inhibitor as the preceding $25 \mathrm{~min}$. before the inhibitor was added. Then, we skipped $25 \mathrm{~min}$ to allow the inhibitor time to take effect. We defined the following $25 \mathrm{~min}$ as time after the inhibitor was added. For 3 slices per condition, we averaged the velocities per cell for the time before and after inhibitor (dynasore $n=15$, vehicle $n=17$, blebbistatin $n=18$, AMP-PNP $n=18)$.

Statistical analysis. We compared the average velocities for each cell before and after inhibitor using the Wilcoxin signed ranks test, a nonparametric analog to the paired $t$ test, in SPSS Statistics 17.0.

\section{Results}

\section{Serotonergic neuron morphology suggests somal translocation}

To investigate the morphology of serotonergic neurons during migration, E10.0 through E13.5 transgenic mouse embryos were cryosectioned and immunostained. Serotonergic neurons were identified by the transgenic label enhanced yellow fluorescent protein driven by the Pet-1 enhancer/promoter region (ePet-EYFP). This transgene labels essentially all serotonergic neurons but may not label $\sim 1-2 \%$ (Scott et al., 2005a). We cannot make any conclu- 
sions about the potentially unlabeled serotonergic neurons, and, therefore, our data represent the vast majority of but not necessarily all serotonergic neurons. The earliest detection of ePet-EYFP was at E10.0. An antibody against YFP was used because the expression of Pet-1 at this stage was low. Typically, Pet-1 was first expressed in cells whose elongated and oval-shaped somata lay about half-way between the ventricular and pial surfaces. At this primitive stage, the cells were bipolar in morphology, with bulb-like endfeet at both the ventricular and pial surfaces (Fig. 1a,b).

At E10.5 detection of ePet-EYFP was still enhanced with the antibody against YFP, but the signal was stronger than at E10.0. ePet-EYFP-expressing neurons continued to maintain their pial and ventricular endfeet (Fig. $1 b$ ), but some neurons began to sprout neurites from their pial process while maintaining their ventricular process (Fig. 1c). Some of these neurites lengthened to form obvious axons that grew along the pial surface, with some extending across the midline. Many immature neurons detached and retracted their ventricular process (Fig. 1d). It is possible, however, that some neurons may not completely retract their ventricular process but, instead, maintain part of the process before its differentiation into dendrites (Morest, 1970). As the cell body neared the pial surface, it became more rounded, and the neurites elongated in a nonfasciculated manner. This sequence of changing patterns of cell morphology was consistent with the possibility that translocation was the mechanism for somal movement.

The movement of serotonergic neurons away from the ventricle continued in waves, with younger neurons appearing as older neurons nearer to the pia further retracted their ventricular processes, extended neurites and began to produce serotonin (5-HT) (Fig. $2 a, b$ ). At E11.5, younger translocating neurons had ventricular processes, while more mature neurons closer to the pial surface elaborated neurites with the meandering morphology of serotonergic axons seen in the adult (Fig. 1e). Through continued birth, migration and maturation of serotonergic neurons, the characteristic sigmoidal shape of the rostral raphe nuclei began to emerge at E12.5 (Fig. 1f). Neurons with a ventricular process were present through at least E13.5, indicating that somal migration continued through at least that stage (data not shown). However, from E11.5 on, the pial processes of migrating neurons were difficult to distinguish from the neurites of more mature cells.

\section{Further characterization of ePet-EYFP-expressing cells}

The transcription factor Pet-1 is necessary for 5-HT production (Hendricks et al., 1999, 2003). Consequently, Pet-1 was expressed earlier than 5-HT. While we found that the earliest expression of Pet-1 was at E10.0, the earliest expression of 5-HT was E10.5, which is consistent with previous findings (Hendricks et al., 1999). Interestingly, the expression of 5-HT coincided with the completion or near completion of radial somal migration (Fig. $2 a, b$ ). The 5-HT-positive neuron (Fig. $2 a$ ) had a long neurite and an almost completely retracted ventricular process. The rounded cell body was positioned near the pial surface, contrasting with
E11.5
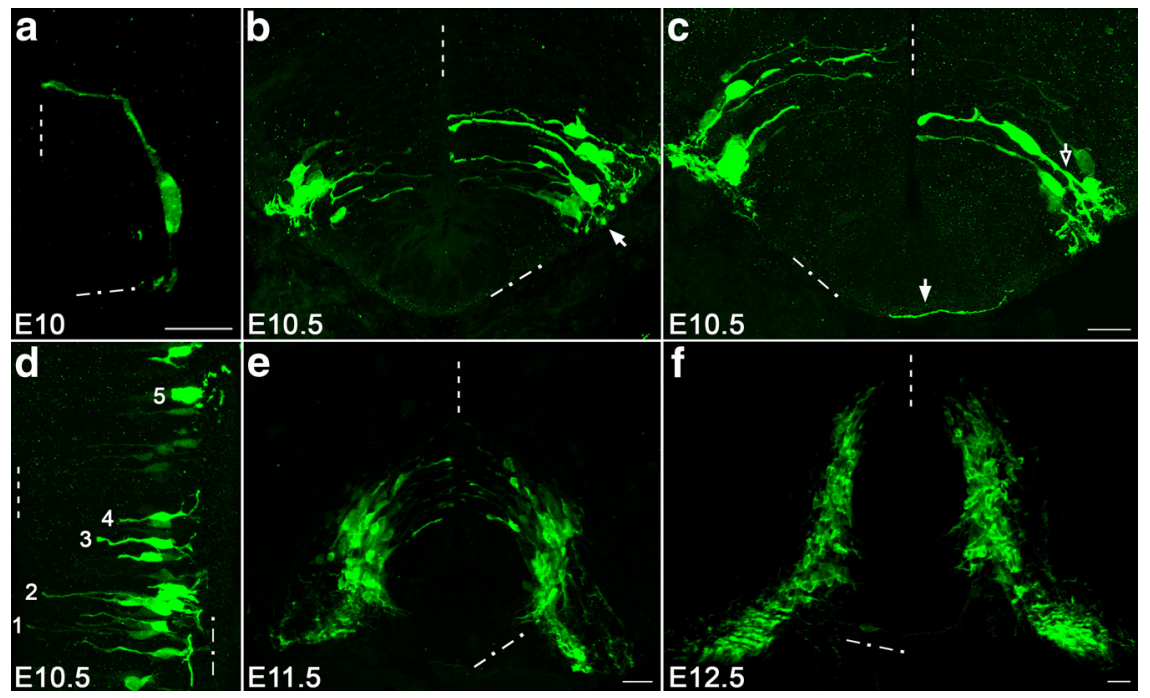

Figure 1. ePet-EYFP-expressing serotonergic neurons exhibited a sequence of changing morphologies suggestive of somal translocation. $\boldsymbol{a}-\boldsymbol{c}$, E10.0-10.5 ePet-EYFP-expressing neurons had bipolar morphology, with endfeet ( $\boldsymbol{b}$, arrow) at both the in progressive stages of ventricular process retraction are labeled $1-5 . \boldsymbol{e}, \boldsymbol{f}$, Neurons migrating at E11.5 (e) and E12.5 (f) form

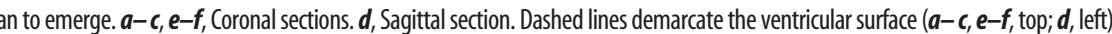
the other neurons that had not finished migration and had elongated cell bodies and shorter neurites. At E12.5 (Fig. 2b) the older, 5-HT-positive neurons were located closer to the pial surface, while the younger, 5-HT-negative neurons were stacked on top of their predecessors ever closer to the ventricular surface. Thus, the waves of newly added neurons were confined to a limited lemniscal-shaped region of young neuroepithelium.

Histological sections were then immunostained for neuronal, glial, and progenitor cell markers to determine the characteristics of early ePet-EYFP-expressing cells and neighboring cells. At E10.5, 99.2\% (132/133) of ePet-EYFP-expressing serotonergic neurons were positive throughout their lengths for TuJ1, an early neuronal-specific $\beta$-tubulin III marker (Fig. $2 c$; supplemental Fig. S1 $a-c$, available at www.jneurosci.org as supplemental material). The one cell that was negative for TuJ1 had a soma located very near the ventricle, so presumably it was more immature than the other ePet-EYFP-expressing cells. Thus, it may be that ePetEYFP expression can precede slightly that of $\beta$-tubulin III in these immature neurons. Retracting ventricular processes were indicated by endballs located away from the pial surface. Tau could be expressed in ventricular processes (Fig. $2 e$; supplemental Fig. S1d-f, available at www.jneurosci.org as supplemental material). Both the ventricular and pial processes could express microtubule associated protein 2 (MAP2) (Fig. 2f; supplemental Fig. $S 1 g-i$, available at www.jneurosci.org as supplemental material). Due to their immature state, not all ePet-EYFP-expressing cells immunostained for tau and MAP2. At E10.5 90\% of ePetEYFP-expressing cells expressed tau, and $\sim 70 \%$ expressed MAP2. The cells with lower expression of ePet-EYFP, indicating that they are likely to be younger cells, were the cells that lacked visible tau or MAP2 expression. The TuJ1, tau and MAP2 staining corroborate that the immature ventricular and pial processes were neuronal. The absence of Ki67 and nestin staining (Fig. 2d; 


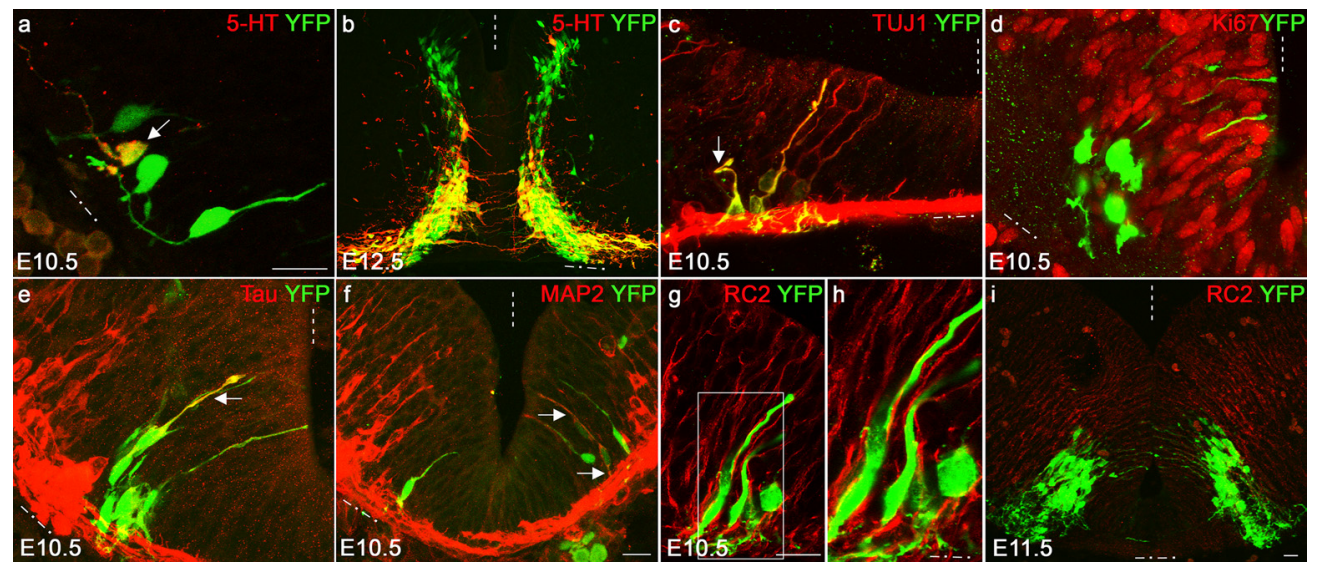

Figure 2. ePet-EYFP-expressing neurons express neuronal markers and coexist with radial glia. $\boldsymbol{a}$, At E10.5, an ePet-EYFP-expressing (green) cell near the pia with a long axon and retracted ventricular process was also positive for 5-HT (red, arrow). $\boldsymbol{b}$, At E12.5, many older neurons closer to the pial surface were 5-HT-positive, seen by double labeling of YFP and 5-HT (yellow), but the younger neurons closer to the ventricle were not yet 5 -HT-positive. c, E10.5 ePet-EYFP-expressing neurons were immunopositive for TuJ1 (red), a neuronal-specific $\beta$-Tubulin III marker. The arrow marks a kink in the retracting ventricular process. $\boldsymbol{d}$, E10.5 ePet-EYFP-expressing serotonergic neurons do not express Ki67 (red), a proliferation marker. $\boldsymbol{e}, \boldsymbol{f}$, At E10.5, ventricular processes express both tau (e, red, arrow) and MAP2 ( $\boldsymbol{f}$, red, arrow), and pial processes express MAP2 (arrow). $\boldsymbol{g}-\boldsymbol{i}$, At E10.5 ( $\boldsymbol{g}, \boldsymbol{h}$ ) and E11.5 (i) ePet-EYFP-expressing neurons did not express a radial glial cell marker RC2 (red), and there were few, if any, points of obvious enwrapping between ePet-EYFP-expressing neurons and radial glia. A higher magnification of the boxed region in $\boldsymbol{g}$ is located in $\boldsymbol{h}$. Dashed lines demarcate the ventricular surface. Dotted and dashed lines mark the pial surface. Coronal sections. Scale bars are the same for $\boldsymbol{b}$ and $\boldsymbol{i} ; \boldsymbol{c}-\boldsymbol{e}, \boldsymbol{g} ; 20 \mu \mathrm{m}$.

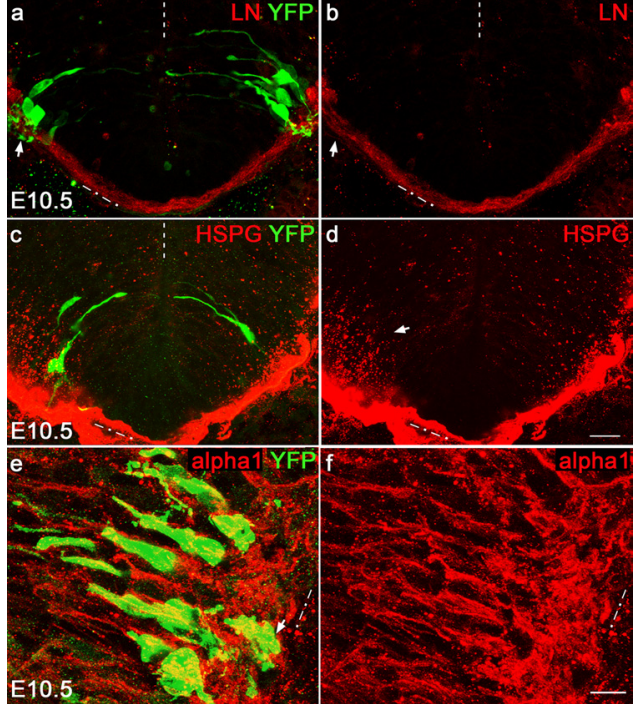

Figure 3. Extracellular matrix proteins laminin, heparan sulfate proteoglycan and integrin $\alpha 1$ were juxtaposed with ePet-EYFP-expressing neurons (green). $\boldsymbol{a}, \boldsymbol{b}$, Laminin (red) immunofluorescence was located just interior to the pial surface during the period of somal translocation. Neurites (arrows) extended along the laminin. $\boldsymbol{c}, \boldsymbol{d}, \mathrm{HSPG}(\boldsymbol{c}$, red) immunofluorescence was punctate $(\boldsymbol{d}$, arrow) and increased toward the pial surface. $\boldsymbol{e}, \boldsymbol{f}$, Higher magnification of $\alpha 1$ integrin (red), a receptor component for laminin, is located in the pial processes of ePet-EYFPexpressing neurons. $\alpha 1$ integrin is also abundant in other cells near the pial surface. Coronal sections. Dashed lines demarcate the ventricular surface. Dotted and dashed lines mark the pial surface. Scale bars are the same for $\boldsymbol{a}-\boldsymbol{d}, 20 \mu \mathrm{m}$ and $\boldsymbol{e}, \boldsymbol{f}, 10 \mu \mathrm{m}$.

data not shown) in ePet-EYFP-expressing cells suggests that they were neither mitotic nor progenitors, upholding that ePet-EYFPexpressing cells were postmitotic. The lack of NeuN staining confirmed that the neurons were indeed young, as NeuN typically labels mature neurons (data not shown).

The radial glial markers glutamate aspartate transporter (GLAST), brain lipid binding-protein (BLBP), radial glial cell 2 (RC2), glial fibrillary acidic protein (GFAP), and vimentin did not colocalize with ePet-EYFP-expressing neurons (Fig. $2 g-i$; supplemental Fig. S1j-o, available at www.jneurosci.org as supplemental material; data not shown). RC2 was the best radial glial marker for
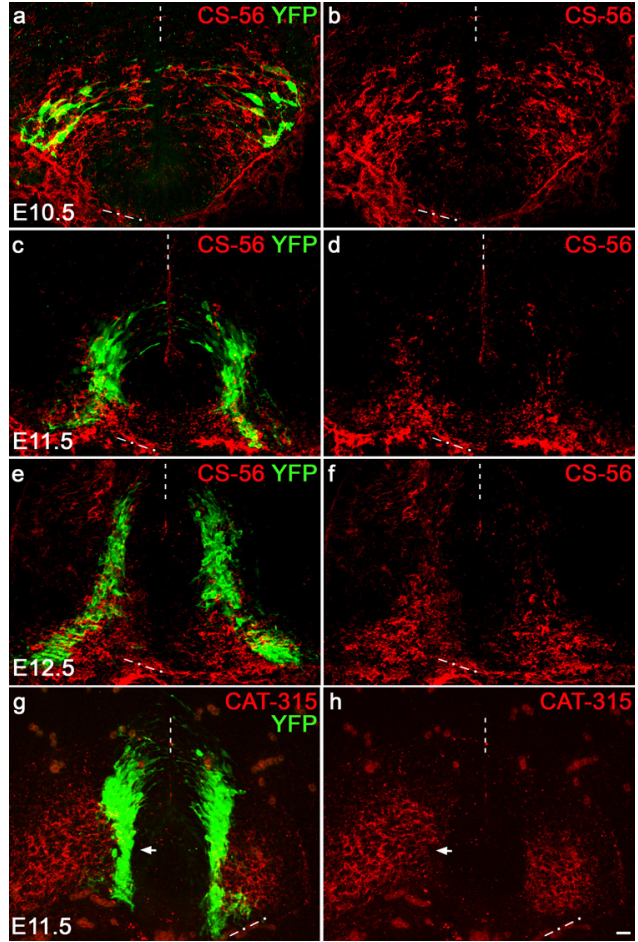

Figure 4. Extracellular matrix proteins chondroitin sulfate proteoglycans surround ePetEYFP-expressing neurons (green). $\boldsymbol{a}-\boldsymbol{f}$, Chondroitin sulfate proteoglycan (CS-56, red) immunofluorescence levels were obviously increased in the territory through which ePet-EYFP neurons translocated. CSPG staining mimicked the shape of the raphe nuclei. $\boldsymbol{a}, \boldsymbol{c}, \boldsymbol{e}$ contain CS-56 and EYFP. $\boldsymbol{b}, \boldsymbol{d}, \boldsymbol{f}$ are CS-56 alone. $\boldsymbol{g}, \boldsymbol{h}$, Chondroitin sulfate proteoglycan aggrecan glycoform CAT315 (red) overlaps and extends laterally to ePet-EYFP-expressing neurons (green). Arrows indicate the medial edge of the ePet-EYFP-expressing neurons. Coronal sections. Dashed lines demarcate the ventricular surface. Dotted and dashed lines mark the pial surface. Scale bar, $20 \mu \mathrm{m}$.

the midbrain/hindbrain at these early embryonic stages, and $0 \%$ (0/44) of ePet-EYFP-expressing neurons colabeled for the radial glial marker RC2. Because of the high density of cells within the neuroepithelium, the young neurons and the radial glia often abutted one 

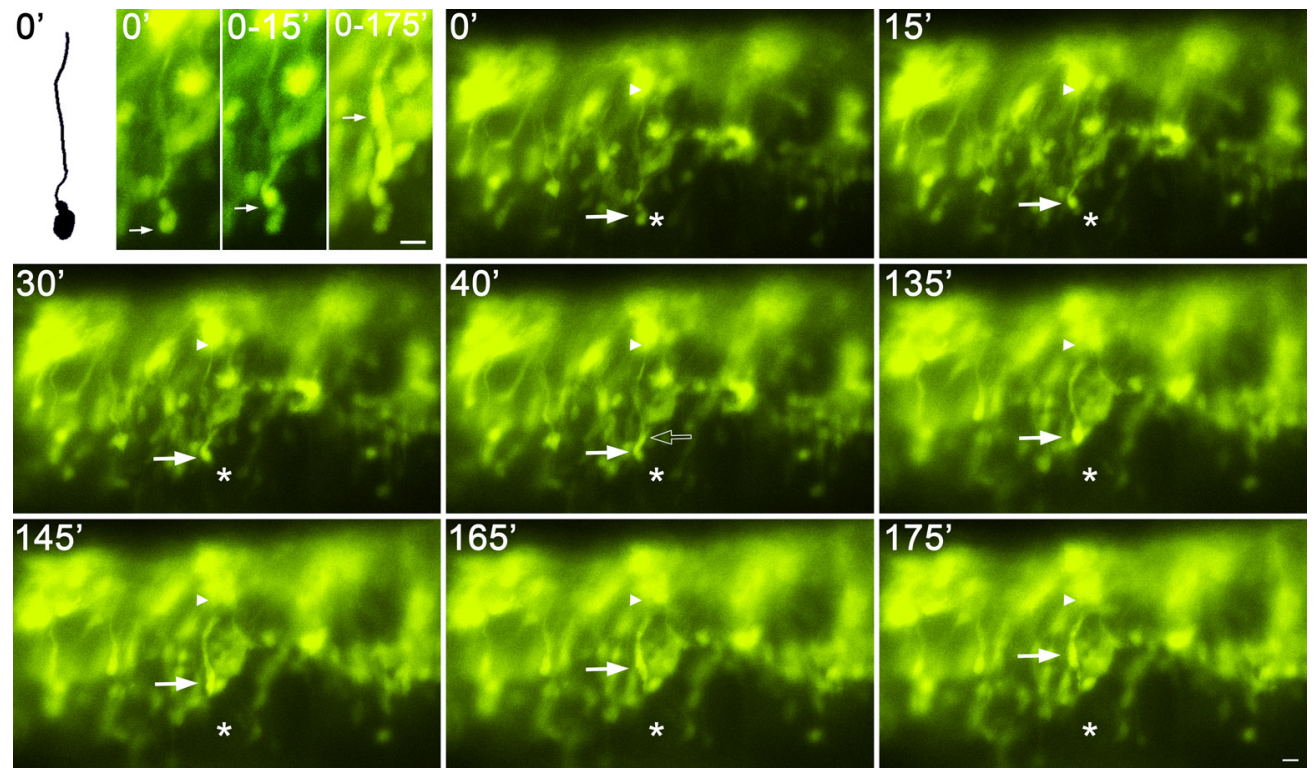

Figure 5. Radial ePet-EYFP-expressing neurons migrated by somal translocation. The first panel contains a tracing of the neuron indicated by the arrow at time 0 min and a projected Z-stack image at $0^{\prime}$. To illustrate the trajectory of the cell body, the movie has also been flattened from time 0 through 15 min and from time 0 through $175^{\prime}$ in the first panel. The small arrows mark the bottom of the cell body at the terminal point in each picture. Many other cells in this section are also at various stages of translocation. The cell bodies elongated and translocated by a series of continuous movements interrupted by pauses. During such movements the cell body elongates, but during pauses the cell body can round up again. Each cell body followed the exact path of its leading process from near the ventricular surface (bottom) toward the pial surface (top). Open arrows point to the swelling that precedes the cell body. Asterisks demarcate the initial position of the cell body. Arrows mark the current position of the cell body. Arrowheads indicate the end of the leading process. E10.5, $200 \mu \mathrm{m}$ sagittal slice. Scale bar, $10 \mu \mathrm{m}$.

another. However, where contact occurred there was no evidence of the extensive and entwined relationship that is characteristic of radial glial-guided locomotion (Rakic, 1971; Noctor et al., 2004).

Together, the radial morphology of the ePet-EYFP-expressing cells, their lack of glial markers, their production of a variety of well characterized neuronal markers, their nonmitotic state, as well as the observation of minimum contacts with radial glia, all suggest that somal translocation is the likely mode of migration of this selected population of neurons.

\section{Growth-promoting and inhibitory extracellular matrices}

The extracellular environment has been shown to influence migration. Perturbations in laminin, integrins, and heparan sulfate proteoglycan (HSPG) cause defects in migration (Galileo et al., 1992; Halfter et al., 2002; Haubst et al., 2006). Chondroitin sulfate proteoglycans (CSPGs) restrict neuronal precursor cell migration in the rostral migratory stream (Gates et al., 1995; Kearns et al., 2003). Extracellular matrix proteins were characterized by immunofluorescence (Figs. 3, 4). The cell bodies of serotonergic neurons migrated toward and elaborated neurites along a layer of potentially growth-promoting laminin at and just interior to the pial surface (Fig. $3 a, b)$.
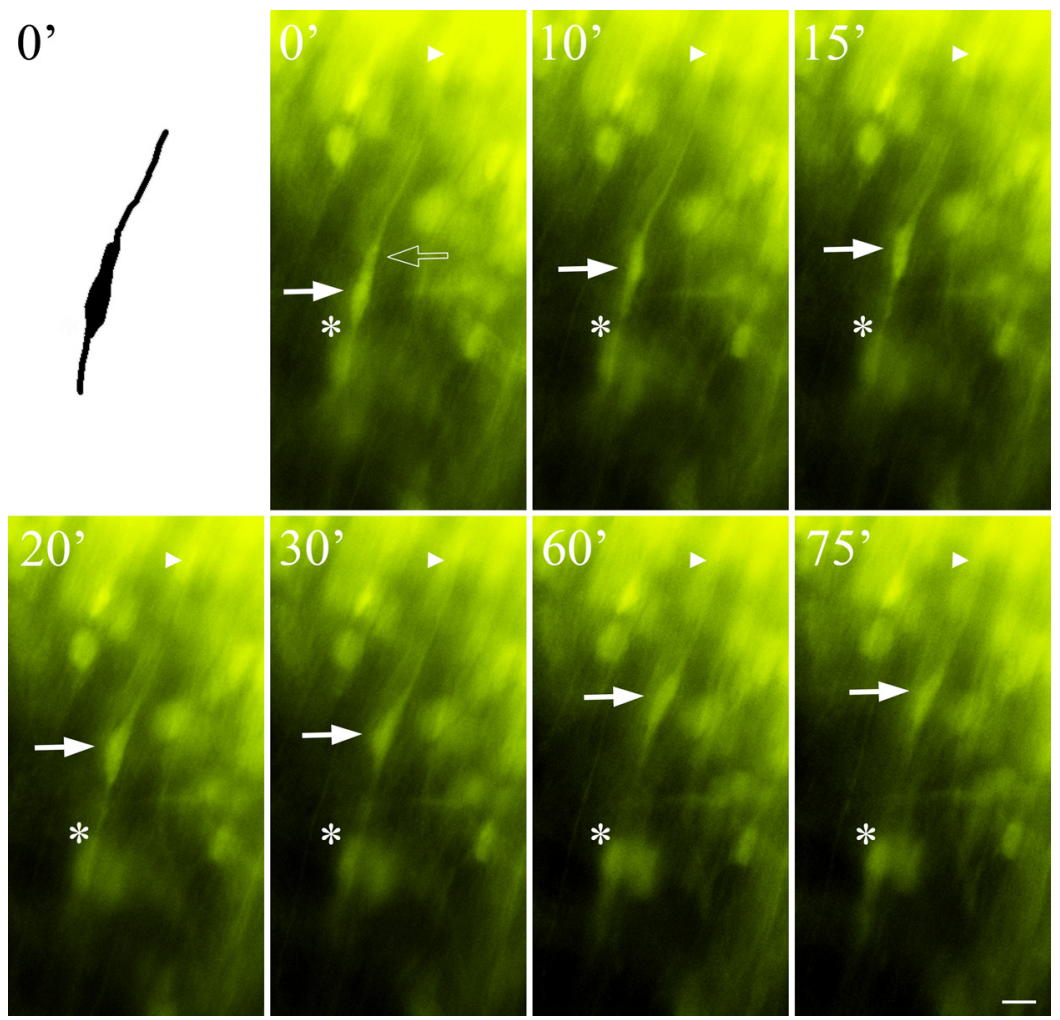

Figure 6. Somal translocation by ePet-EYFP-expressing bipolar, radial neurons at higher magnification. A tracing of the neuron at time $0 \mathrm{~min}$ is in the first panel. The cell body translocated from near the ventricular surface (bottom) along its leading process toward the pial surface (top). An open arrow marks the swelling that translocated before the cell body. Note how the elongated cell body changed shape during translocation. Only a short trailing process remained at $75^{\prime}$, while the leading process was still maintained. Asterisks demarcate the initial position of the cell body. Filled arrows mark the current position of the cell body. Arrowheads indicate the end of the leading process (top). E11.5, $200 \mu \mathrm{m}$ sagittal slice. Scale bar, $10 \mu \mathrm{m}$. 


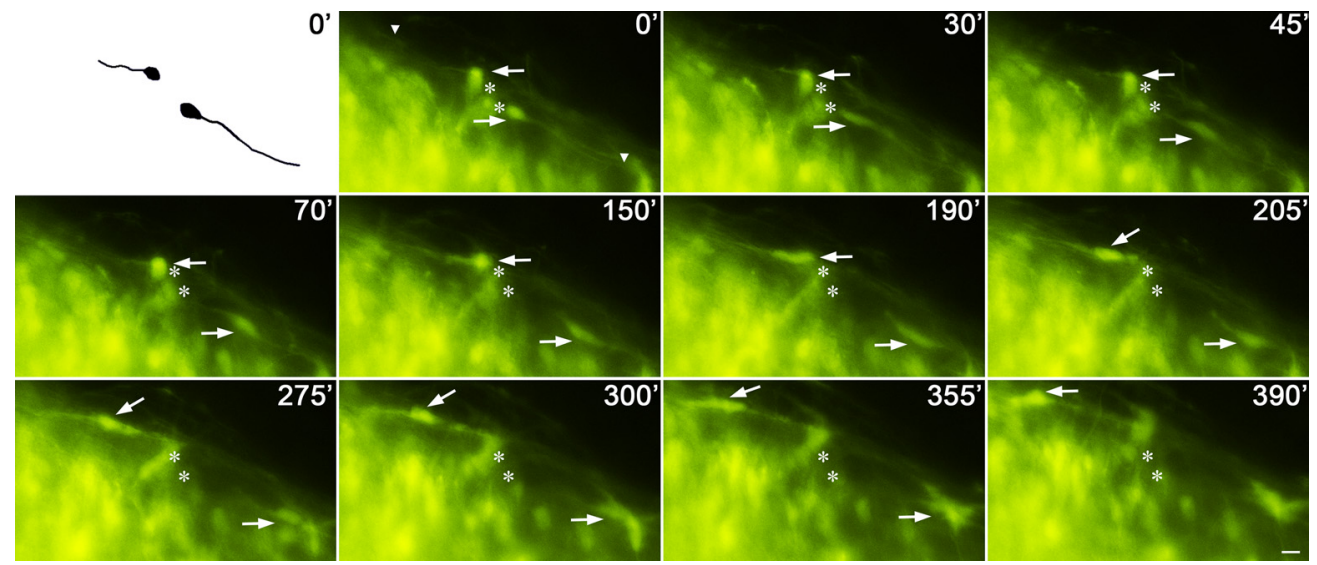

Figure 7. More mature ePet-EYFP-expressing serotonergic neurons can also translocate in a tangential direction. Two neurons (arrows) traveling in opposite rostrocaudal directions are traced in the first panel. The neuron in the lower right moves first. The cell body elongates $\left(30^{\prime}\right)$ and translocates rostrally (right) along the path of its leading process. The second neuron in the upper left then elongates $\left(190^{\prime}\right)$ and translocates caudally (left) following its leading process. Asterisks demarcate the initial position of the cell body. Arrows mark the current position of the cell body. Arrowheads mark the leading processes. E11.5, $200 \mu \mathrm{m}$ sagittal slice. Scale bar, $10 \mu \mathrm{m}$.

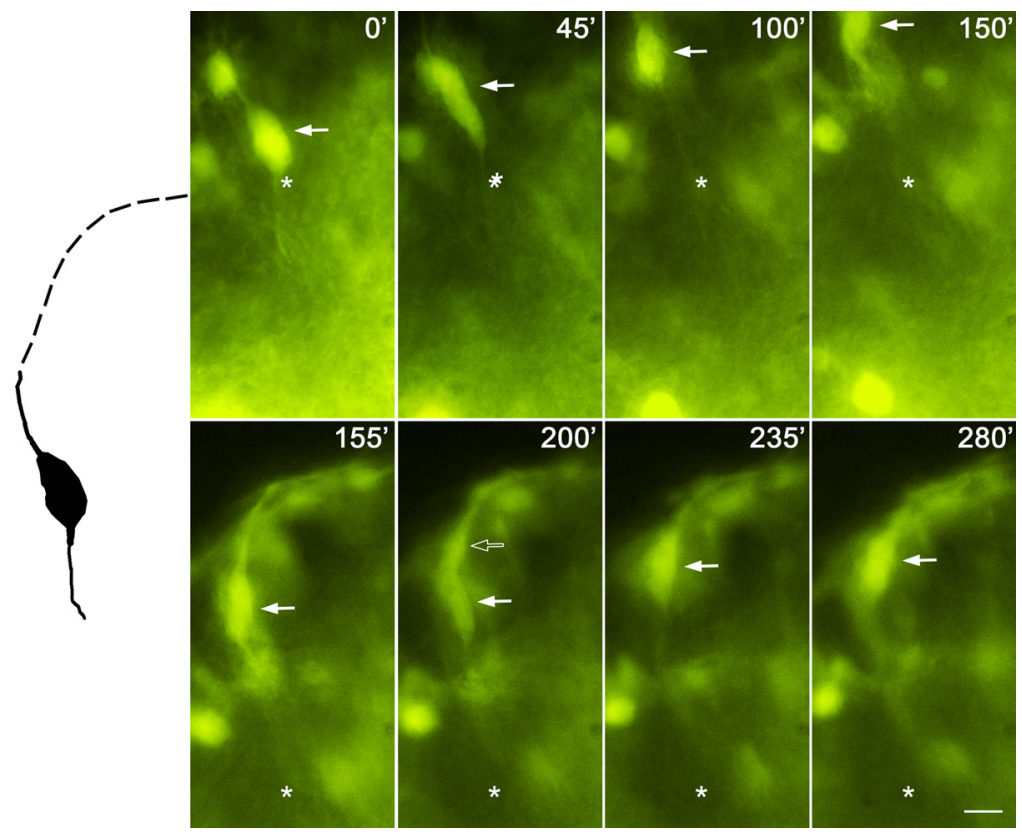

Figure 8. After initial radial translocation, the cell body can follow its leading process to turn and translocate along the pia surface. A tracing of the neuron at $0^{\prime}$ is in the first panel with its leading process extrapolated (dotted lines) based on 155-280'. The cell body translocated through the leading process by elongating $\left(45^{\prime}, 200^{\prime}\right)$ and rounding up again $\left(100^{\prime}, 280^{\prime}\right)$. The open arrow points to the swelling that precedes the cell body. Note that the trajectory of the leading process follows the pial surface. Asterisks demarcate the initial position of the cell body. E11.5, $250 \mu \mathrm{m}$ coronal slice. Scale bar, $10 \mu \mathrm{m}$.

Fibronectin was not detected in the vicinity of the serotonergic neurons from E10.0 to E13.5 (data not shown). At E10.5, HSPG was also located in the basal lamina and in a punctate pattern near the pial surface and extending slightly inward (Fig. $3 c, d$ ). The receptors for laminin are integrins, made up of $\alpha$ and $\beta$ subunits. We immunostained for probable $\alpha$ subunits contributing to laminin receptors, integrin $\alpha 1, \alpha 2, \alpha 3$, and $\alpha 6$ (Milner and Campbell, 2002). Integrin $\alpha 1$ immunostaining was present near the pial surface in ePet-EYFPexpressing cells (Fig. $3 e, f$ ). Integrin $\alpha 2$ immunostaining was not detected in the raphe region (data not shown). Integrin $\alpha 3$ was present at high levels in cells in the floor plate (data not shown). Integrin $\alpha 6$ was present, but not contained within ePet-EYFP-expressing cells (data not shown).
The expression pattern of CSPGs, labeled by the antibody CS-56, was specific to the path of migration of ePet-EYFPexpressing neurons (Fig. 4a-f). At E10.5, migrating neurons were completely surrounded by CSPG (Fig. $4 a, b$ ). At E11.5 and E12.5, the CSPG levels were highest at the lateral borders of the pool of serotonergic neurons (Fig. $4 c-f$ ). We then examined specific CSPGs, but most CSPG-specific antibodies are not ideal for mouse. Tenascin immunostaining was absent (data not shown). Antibodies against aggrecan CAT-301 and CAT-316 (Matthews et al., 2002) faintly stained (data not shown), and CAT-315 stained robustly in a different region than CS-56, staining in the area of migrating cell bodies and, in addition, just lateral to the serotonergic neurons (Fig. $4 g-h$ ). So, certain glycoforms of aggrecan are components of CSPGs in the embryonic raphe.

\section{Slice culture time-lapse imaging verified somal translocation}

The histological data provided us with the basic understanding of the morphology, markers, and location of the ePet-EYFPexpressing cells. However, to truly show that the neuron's cell body was moving by translocation, we viewed the ePet-EYFP-expressing serotonergic neurons by timelapse imaging in slice culture. We cultured E10.5-E11.5 slices on organotypic filters and viewed EYFP $2 \mathrm{~d}$ later by fluorescence time-lapse imaging. In time-lapse imaging of a sagittal slice (Fig. 5; supplemental Movie 1, available at www.jneurosci.org as supplemental material), ePet-EYFP-expressing neurons translocated from near the ventricle to near the pial surface. The cell body (Fig. 5 , arrow) was initially located near the ventricle, and the cell had a long leading process extending toward the pial surface. No trailing process was detectable at time $0 \mathrm{~min}$ but is visible at later times (165-175 $\mathrm{min})$. The cell body followed the exact path laid 
out by the leading process while traveling from the ventricle toward the pial surface, which can be seen in flattened versions of the movie from 0 to $15 \mathrm{~min}$ and from 0 to $175 \mathrm{~min}$ in the first panel. The soma stopped translocating when reaching a position near the pial surface, usually within a group of ePet-EYFP-expressing cell bodies. Many other neurons in the slice were also in various stages of translocation toward the pia.

A higher magnification view of a translocating cell body shows that the neuron was bipolar and had clear leading and trailing processes (Fig. 6, sagittal slice). The cell body was elongated and preceded by a swelling, most likely the centrosome and Golgi apparatus (Tanaka et al., 2004; Bellion et al., 2005; Tsai et al., 2007). The translocating cell body changed shape as it squeezed through the leading process straight toward a group of cell bodies nearer to the pial surface. The trailing process was gradually lost, while the leading process was maintained. Thus, our results are consistent with ePet-EYFP-expressing serotonergic neurons migrating from the ventricle to the pial surface by somal translocation.

After the initial stage of migration from the ventricle is complete, the neurons must still group themselves into the proper shape of the raphe nuclei. Some neurons in the slice that were already detached from the outer and inner limiting membranes migrated further along the pia in a rostral or caudal direction within a neurite (Fig. 7; supplemental Movie 2, sagittal slice, available at www.jneurosci.org as supplemental material). The leading process continued extension along the pial surface, and then the cell body translocated a distance and paused. A short trailing process is also visible. This may be a separate form of migration, a mixture of tethered translocation and the whole-cell movement of tangential migration.

The neurons can become oriented rostrocaudally along the pial surface by simply following their leading neurite (Fig. 8; supplemental Movie 3, available at www.jneurosci.org as supplemental material). Similar to Figure $2 a$, this neuron in a coronal slice has a leading process reaching and extending along the pial surface. The bipolar neuron translocated first radially and then followed the path of the leading process to align rostrocaudally at the pial surface.

Serotonergic neurons can continue such movement using a combination of translocation and migration (Fig. 9, sagittal slice). Even after the neurons have several neurites extending in different directions, the cell body can translocate into one of these processes. The morphology of the cell body during these movements is the same as is seen in radial somal translocation. In this manner, the cell body continues to change direction, perhaps enabling the neuron to fine-tune its final destination.

ePet-EYFP-expressing neurons translocated at an average speed of $17.5 \pm 12.3 \mu \mathrm{m} \mathrm{h}^{-1}(\mathrm{SD})$. We graphed the velocity during each $5 \mathrm{~min}$ interval for the trailing side of the nucleus in the selected cells from Figure 5/supplemental Movie 1 (available at www.jneurosci.org as supplemental material), Figure 6, and Figure 8/supplemental Movie 3 (available at www.jneurosci.org as supplemental material) (Fig. 10). The speed of translocation constantly varied and consisted of a mixture of continuous

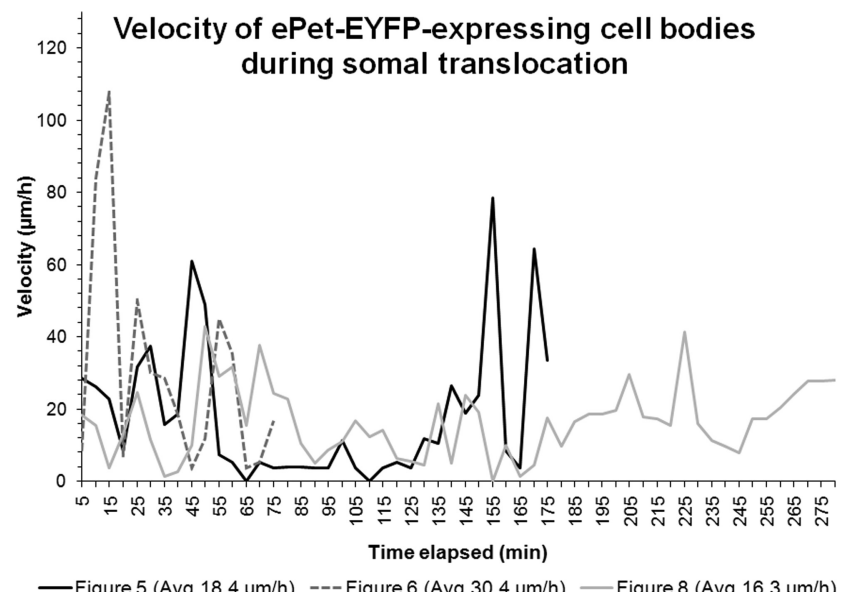

Figure 10. Quantification of the velocity ePet-EYFP-expressing neuronal cell bodies translocated over time. The trailing ends of the cell bodies in Figures 5, 6, and 8 were tracked over time. The velocities of the cell bodies were not constant, but were marked with pauses and increases and decreases in speed. The speeds over each 5 min interval ranged from 0 to 107.5 $\mu \mathrm{m} / \mathrm{h}$. The average speeds were $18.4 \mu \mathrm{m} / \mathrm{h}$ for Figure 5, $30.4 \mu \mathrm{m} / \mathrm{h}$ for Figure 6 , and 16.3 $\mu \mathrm{m} / \mathrm{h}$ for Figure 8 .

movements and pauses. Of the 205 ePet-EYFP-expressing neurons observed translocating in the slice, $136(66.3 \%)$ translocated radially through their pial process, $50(24.4 \%)$ translocated in several directions through their neurites, 19 (9.3\%) translocated rostrocaudally along the pial surface through their leading neurite, presumably an axon, and $0(0 \%)$ migrated as a cohesive unit with the leading process. The primary goal of the study was to observe neurons translocating in a radial direction, and the other forms of translocation were seen in more mature slices when radial translocation was nearly complete. Hence, the lower numbers of observation for translocation through neurites or rostrocaudally do not necessarily indicate their overall prevalence, but merely indicate that in younger tissue radial translocation dominates. In older tissue the reverse is likely true.

Dynamin participates in the somal translocation mechanism Dynamin is a large protein GTPase that functions in microtubule dynamics (Shpetner and Vallee, 1989; Tanabe and Takei, 2009), 

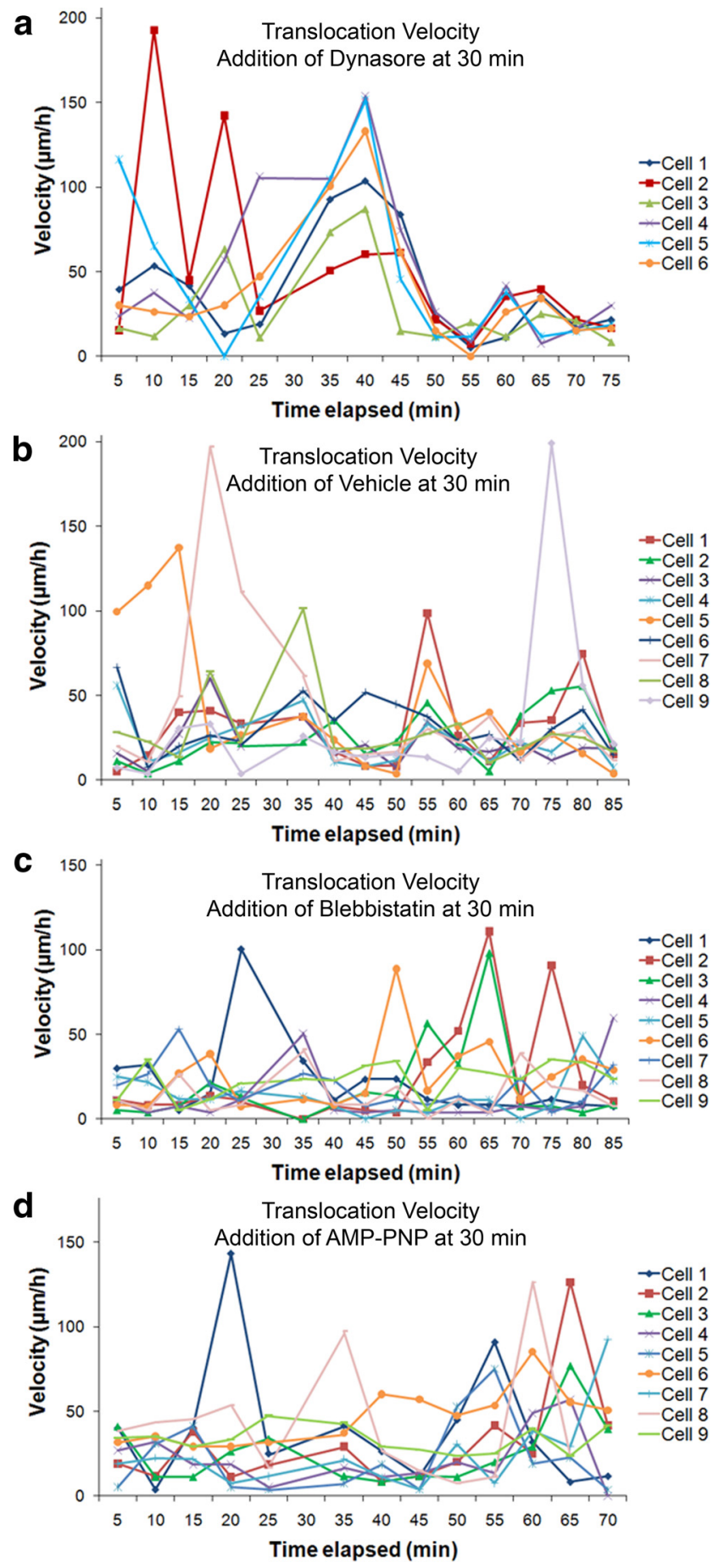

Figure 11. The dynamin inhibitor dynasore causes translocation in ePet-EYFP-expressing neurons to slow down $(\boldsymbol{a})$, while vehicle control $(\boldsymbol{b})$, the myosin II inhibitor blebbistatin $(\boldsymbol{c})$, and the kinesin inhibitor AMP-PNP (d) have no significant effect. Velocities during each 5 min interval are shown for cells in one representative slice for each treatment. The treatment was applied to the slice at $30 \mathrm{~min}$.

vesicle formation (Allan et al., 2002), directed non-neuronal cell migration (Thelen et al., 2002; Ezratty et al., 2005; Le Roy and Wrana, 2005; Macia et al., 2006) and growth cone chemorepulsion (Kolpak et al., 2009). Neurons express dynamins 1, 2 and possibly 3 (Kruchten and McNiven, 2006), but the role of dynamin has not been investigated in neuronal migration. We hypothesized that dynamin is involved in the directed movement of somal translocation. We also tested the motors nonmuscle myosin II, which may act as a pushing force behind the nucleus (Bellion et al., 2005), and kinesin, which is not likely to participate in migration because it is a plus-end directed motor and acts as a negative control. To investigate the mechanism by which neurons translocate, a variety of inhibitors were added to the bath and/or injected into the slice after $25 \mathrm{~min}$ of baseline observation. ePet-EYFP-expressing cells from a representative slice treated with $80 \mu \mathrm{M}$ dynasore at $30 \mathrm{~min}$ were traced and the velocities of the cell bodies during each 5 min interval were graphed (Fig. 11a). After allowing dynasore to take effect for 25 $\mathrm{min}$, the average velocity for the next 25 min was compared to the average velocity for $25 \mathrm{~min}$ before dynasore was added. Dynasore treatment significantly decreased the average velocity of translocation (Wilcoxin ranked signs test, $\mathrm{Z}=-2.499, p=0.012, n=15$ ). Vehicle control (Fig. 11b, $n=17$ ), $100 \mu \mathrm{M}$ nonmuscle myosin II inhibitor blebbistatin (Fig. 11c, $n=18$ ), and $1 \mathrm{~mm}$ kinesin inhibitor adenosine $5^{\prime}-(\beta, \gamma$-imido $)$ triphosphate tetralithium salt hydrate (AMP-PNP) (Fig. $11 d, n=18$ ), all had no significant effect on translocation. Since there are no fast-acting, specific drugs to block dynein, we were unable to test if dynein was involved in translocation.

\section{Discussion}

The promoter and enhancer region of the transcription factor Pet-1 driving EYFP is an unequivocal marker of serotonergic neurons from development into adulthood, which gave us an unprecedented opportunity to observe the migration of the vast majority of serotonergic neurons from their germinal zone to the raphe. Our immunohistochemical analyses of staged, fixed tissue and time-lapse imaging of living slices have revealed that the early movement of the cell body toward the raphe, as well as its further positioning within the raphe, are accomplished by somal translocation (Fig. 12). While translocation does not require a physical scaffold of radial glia, radial glia may be the immediate neuronal precursors. We found no overlap of glial and neuronal markers within serotonergic neurons, but glial antigens could switch off too quickly to be codetected. The early and continuing presence of radial glia surrounding serotonergic neurons suggests that the glia could influence 5-HT neuronal migration or differentiation indirectly, for instance via secretion of trophic substances like S-100 $\beta$ (Azmitia et al., 1990; Gomez et al., 1990).

The length of time the pial process is attached varies across cell types, and its persistence or detachment could determine the amount of distance traveled and/or contribute to the final shape of nuclei or position of laminae. Both cortical pyramidal and retinal ganglion neurons maintain pial endfeet throughout most of their translocation and, therefore, travel further toward the outer limiting membrane (Brittis et al., 1995). Radial glia that differentiate as pial glia never detach their pial process and translocate to the pial surface (Schmechel and Rakic, 1979). Motor neurons also translocate their nuclei, but they do not detach their pial process. Rather, they elaborate an axon from the pial process and extend it beyond the outer limiting membrane (LTL, unpublished data). Serotonergic neurons do not form laminae, but pile upon one another, forming a narrow shelf (Figs. 1e,f, 2b). By detaching the pial processes relatively early during translocation, later-born serotonergic neurons may collect part-way between the ventricle and pia, generating the outside-in sequence of cell addition.

Serotonergic neurons form sigmoid-shaped rostral raphe nuclei. The lateral displacement of 5-HT neurons may be confined by CSPGs. While CS-56-labeled CSPGs surround ePet-EYFPexpressing cells (Fig. 4a-d), aggrecan glycoforms also lie laterally 
(Fig. 4e,f). CSPGs fill the adult subventricular zone and may restrict progenitor cell migration to the rostral migratory stream (Gates et al., 1995; Kearns et al., 2003). Likewise, CSPGs might confine serotonergic neuron translocation within the limits of the raphe, especially after pial process detachment. This additional role for CSPGs in cell migration is different from their role of inhibiting axons after injury. Here, CSPGs may act like a corral for the cell bodies, which are constrained to migrate within but not outside of the CSPG-laden terrain. On the contrary, axons leave the area of highest CSPGs to follow the laminin- and HSPG-rich pial surface.

We postulate that the pial endfoot and emerging neurites bind to laminin and HSPG in and around the basement membrane (Fig. $3 a-d$ ) through integrin receptors (Fig. $3 e, f$ ), conferring directionality and polarity to translocating neurons and their axons (Chiu et al., 1986), especially at early stages. In classic papers, an antisense retrovirus against $\beta 1$ or $\alpha 6$ integrin was introduced into the chick E3 optic tectum, and neuronal migration became highly abnormal by E9: pial endfeet were detached (possibly disallowing a pial signal), and cells accumulated in the ventricular zone (Galileo et al., 1992; Zhang and Galileo, 1998). Translocation was shown to be the major mode of migration in neurons in the optic tectum (Snow and Robson, 1995). Radial glia detachment from the pial surface and defects in neuronal migration are also characteristic of mice deficient in $\alpha 6$ (Haubst et al., 2006) and $\beta 1$ integrins (GrausPorta et al., 2001; Belvindrah et al., 2007). Additionally, migration was perturbed by degradation of collagen or a mutation of the nidogen binding site of the laminin $\gamma 1$ chain (Halfter et al., 2002), or by the removal of perlecan (Haubst et al., 2006) (an HSPG) or focal adhesion kinase (FAK) (Beggs et al., 2003). Motor neurons with the spinal muscular atrophy gene SMN knocked-down by shRNA aberrantly translocate well beyond the CNS border through breaks in the basal lamina (C. E. Krull, unpublished data). So, an intact connection with the basement membrane is likely to be necessary for proper radial translocation.

How might integrins confer information about the basement membrane to the cytoskeleton? Integrins can signal through FAK to Rho and mammalian homolog of Diaphanous, an effector protein of Rho, to stabilize microtubules at the leading edge of the cell (Palazzo et al., 2004). ePet-EYFP-expressing neurons, even at an early age, contain type III $\beta$-tubulin (Fig. $2 c$ ), a component of microtubules. Contact of lamellipodia with the extracellular matrix signals both integrins and Rac to drive migration progressively forward (Ridley, 2001). However, whole-cell migration requires turnover and stabilization of the leading edge to move forward, which involves the actin cytoskeleton (Ridley, 2001). Since translocating neurons have a stabilized pial process, movement of their cell body and retraction of their trailing process can be accomplished using microtubules (Ballestrem et al., 2000; Ridley, 2001; Dujardin and Vallee, 2002).

Integrin signaling can impart directional information to the cell when its ligand is localized. The large GTPase dynamin pinches off vesicles during endocytosis to internalize receptors, such as integrins, thereby localizing signals (Thelen et al., 2002; Le Roy and Wrana, 2005). FAK recruits dynamin to focal adhesions for disassembly (Ezratty et al., 2005), and both FAK and dynamin are also located at the centrosome (Xie et al., 2003; Thompson et al., 2004). FAK inhibition disrupts migration and nucleokinesis in cortical neurons (Xie et al., 2003). We discovered that inhibition of dynamin disrupts somal translocation in serotonergic neurons. We cannot completely eliminate the possibility, though unlikely given the known direct effects of dynasore and the quick action of the inhibitor, that dynasore is not inhibiting translocation directly but instead is inhibiting a signal from a neighboring cell, which acts on the rate of translocation. Nonetheless, FAK and dynamin may be vital to neuronal migration, but whether these two enzymes work cooperatively in both translocation and locomotion is unknown.

Dynamin also regulates the dynamic instability of microtubules (Shpetner and Vallee, 1989; Tanabe and Takei, 2009), formation of the Golgi apparatus (Allan et al., 2002; Tanabe and Takei, 2009), cohesion of the centrosome and organization of the microtubule organizing center (Thompson et al., 2004). During nucleokinesis, the centrosome and Golgi apparatus extend before the nucleus in a swelling (Tanaka et al., 2004; Bellion et al., 2005; Tsai et al., 2007). We observed this swelling in serotonergic neurons, which closely resembles the morphology of the swelling in tangential migration nucleokinesis. Dynamin inhibition could disrupt the centrosome/Golgi complex, interfering with movement of the centrosome/Golgi and, subsequently, the entire cell body.

Dynamin inhibition decreased translocation velocity but did not stop it completely. Dynasore blocks dynamin 1 and 2, but compensation could occur in neurons with dynamin 3 . However, involvement is expected from another component of the motor. Inhibitors of nonmuscle myosin II and kinesin had no effect on serotonergic neuron translocation. Therefore, the other motor component is most likely dynein, which would pull the nucleus along the microtubule network (Tanaka et al., 2004; Tsai et al., 2007). Since there are no fast-acting, specific drugs to block dynein, and the early migration of serotonergic neurons makes in utero injection of constructs prohibitively difficult, we were unable to test if dynein was involved. Somal translocation is quite different from radial glial-guided locomotion (Schaar and McConnell, 2005), neuronal precursor migration (Tsai et al., 2007) and tangential migration (Bellion et al., 2005) because translocation does not rely on myosin II as a pushing force.

Doublecortin (DCX), lissencephaly-1, and Ndel1/mNudE couple the nucleus and the centrosome in cortical neurons (Feng 
et al., 2000; Shu et al., 2004; Tanaka et al., 2004). In a Dcx shRNA knock-down, reintroducing DCX postnatally at postnatal day 0 (P0) or P5 allowed a remarkable rescue of migration for cortical pyramidal neurons stalled near the ventricle (Manent et al., 2009). At these postnatal ages, the radial glia have differentiated, no longer forming an aligned scaffolding from the ventricle to the pia (Misson et al., 1988). Reelin, a molecule important for proper corticogenesis (Gupta et al., 2003), would only be made near the pial surface. So, it is unlikely that ectopic cortical neurons could resume their migration solely by radial glial-guided locomotion. However, neurons with pial projections could move within them once their connection to the motor was restored, which raises the possibility that certain types of cortical neurons may use translocation as their normal mode of migration.

In summary, we show definitive evidence that serotonergic neurons migrate by somal translocation mediated partially by dynamin. Future studies may reveal dynamin as a vital component in other forms of neuronal migration. With the advent of early, stable, genetic markers that label other specific neuronal populations, somal translocation may be shown to be a widespread migratory phenomenon throughout the CNS.

\section{References}

Allan VJ, Thompson HM, McNiven MA (2002) Motoring around the Golgi. Nat Cell Biol 4:E236-242.

Azmitia EC, Dolan K, Whitaker-Azmitia PM (1990) S-100B but not NGF, EGF, insulin or calmodulin is a CNS serotonergic growth factor. Brain Res 516:354-356.

Ballestrem C, Wehrle-Haller B, Hinz B, Imhof BA (2000) Actin-dependent lamellipodia formation and microtubule-dependent tail retraction controldirected cell migration. Mol Biol Cell 11:2999-3012.

Bananis E, Murray JW, Stockert RJ, Satir P, Wolkoff AW (2000) Microtubule and motor-dependent endocytic vesicle sorting in vitro. J Cell Biol 151:179-186.

Beggs HE, Schahin-Reed D, Zang K, Goebbels S, Nave KA, Gorski J, Jones KR, Sretavan D, Reichardt LF (2003) FAK deficiency in cells contributing to the basal lamina results in cortical abnormalities resembling congenital muscular dystrophies. Neuron 40:501-514.

Bellion A, Baudoin JP, Alvarez C, Bornens M, Métin C (2005) Nucleokinesis in tangentially migrating neurons comprises two alternating phases: forward migration of the Golgi/centrosome associated with centrosome splitting and myosin contraction at the rear. J Neurosci 25:5691-5699.

Belvindrah R, Graus-Porta D, Goebbels S, Nave KA, Müller U (2007) Beta1 integrins in radial glia but not in migrating neurons are essential for the formation of cell layers in the cerebral cortex. J Neurosci 27:13854-13865.

Borrell V, Kaspar BK, Gage FH, Callaway EM (2006) In vivo evidence for radial migration of neurons by long-distance somal translocation in the developing ferret visual cortex. Cereb Cortex 16:1571-1583.

Brittis PA, Meiri K, Dent E, Silver J (1995) The earliest patterns of neuronal differentiation and migration in the mammalian central nervous system. Exp Neurol 134:1-12.

Cheng L, Chen CL, Luo P, Tan M, Qiu M, Johnson R, Ma Q (2003) Lmx1b, Pet-1, and Nkx2.2 coordinately specify serotonergic neurotransmitter phenotype. J Neurosci 23:9961-9967.

Chiu AY, Matthew WD, Patterson PH (1986) A monoclonal antibody that blocks the activity of a neurite regeneration-promoting factor: studies on the binding site and its localization in vivo. J Cell Biol 103:1383-1398.

Ding YQ, Marklund U, Yuan W, Yin J, Wegman L, Ericson J, Deneris E, Johnson RL, Chen ZF (2003) Lmxlb is essential for the development of serotonergic neurons. Nat Neurosci 6:933-938.

Dujardin DL, Vallee RB (2002) Dynein at the cortex. Curr Opin Cell Biol 14:44-49.

Ezratty EJ, Partridge MA, Gundersen GG (2005) Microtubule-induced focal adhesion disassembly is mediated by dynamin and focal adhesion kinase. Nat Cell Biol 7:581-590.

Feng Y, Olson EC, Stukenberg PT, Flanagan LA, Kirschner MW, Walsh CA (2000) LIS1 regulates CNS lamination by interacting with mNudE, a central component of the centrosome. Neuron 28:665-679.

Galileo DS, Majors J, Horwitz AF, Sanes JR (1992) Retrovirally introduced antisense integrin RNA inhibits neuroblast migration in vivo. Neuron 9:1117-1131.

Gates MA, Thomas LB, Howard EM, Laywell ED, Sajin B, Faissner A, Götz B, Silver J, Steindler DA (1995) Cell and molecular analysis of the developing and adult mouse subventricular zone of the cerebral hemispheres. J Comp Neurol 361:249-266.

Gomez LA, Brusco A, Saavedra JP (1990) Immunocytochemical study of S-100 positive glial cells in the brainstem and spinal cord of the rat embryo. Int J Dev Neurosci 8:55-64.

Goridis C, Rohrer H (2002) Specification of catecholaminergic and serotonergic neurons. Nat Rev Neurosci 3:531-541.

Graus-Porta D, Blaess S, Senften M, Littlewood-Evans A, Damsky C, Huang Z, Orban P, Klein R, Schittny JC, Müller U (2001) Beta1-class integrins regulate the development of laminae and folia in the cerebral and cerebellar cortex. Neuron 31:367-379.

Gupta A, Sanada K, Miyamoto DT, Rovelstad S, Nadarajah B, Pearlman AL, Brunstrom J, Tsai LH (2003) Layering defect in p35 deficiency is linked to improper neuronal-glial interaction in radial migration. Nat Neurosci 6:1284-1291.

Halfter W, Dong S, Yip YP, Willem M, Mayer U (2002) A critical function of the pial basement membrane in cortical histogenesis. J Neurosci 22:6029-6040.

Haubst N, Georges-Labouesse E, De Arcangelis A, Mayer U, Götz M (2006) Basement membrane attachment is dispensable for radial glial cell fate and for proliferation, but affects positioning of neuronal subtypes. Development 133:3245-3254.

Hendricks T, Francis N, Fyodorov D, Deneris ES (1999) The ETS domain factor Pet- 1 is an early and precise marker of central serotonin neurons and interacts with a conserved element in serotonergic genes. J Neurosci 19:10348-10356.

Hendricks TJ, Fyodorov DV, Wegman LJ, Lelutiu NB, Pehek EA, Yamamoto B, Silver J, Weeber EJ, Sweatt JD, Deneris ES (2003) Pet-1 ETS gene plays a critical role in 5-HT neuron development and is required for normal anxiety-like and aggressive behavior. Neuron 37:233-247.

Hinds JW, Hinds PL (1974) Early ganglion cell differentiation in the mouse retina: an electron microscopic analysis utilizing serial sections. Dev Biol $37: 381-416$.

Honda T, Tabata H, Nakajima K (2003) Cellular and molecular mechanisms of neuronal migration in neocortical development. Semin Cell Dev Biol 14:169-174.

Kearns SM, Laywell ED, Kukekov VK, Steindler DA (2003) Extracellular matrix effects on neurosphere cell motility. Exp Neurol 182:240-244.

Kolpak AL, Jiang J, Guo D, Standley C, Bellve K, Fogarty K, Bao ZZ (2009) Negative guidance factor-induced macropinocytosis in the growth cone plays a critical role in repulsive axon turning. J Neurosci 29:10488-10498.

Kruchten AE, McNiven MA (2006) Dynamin as a mover and pincher during cell migration and invasion. J Cell Sci 119:1683-1690.

Le Roy C, Wrana JL (2005) Clathrin- and non-clathrin-mediated endocytic regulation of cell signalling. Nat Rev Mol Cell Biol 6:112-126.

Levitt P, Moore RY (1978) Developmental organization of raphe serotonin neuron groups in the rat. Anat Embryol 154:241-251.

Macia E, Ehrlich M, Massol R, Boucrot E, Brunner C, Kirchhausen T (2006) Dynasore, a cell-permeable inhibitor of dynamin. Dev Cell 10:839-850.

Manent JB, Wang Y, Chang Y, Paramasivam M, LoTurco JJ (2009) Dcx reexpression reduces subcortical band heterotopia and seizure threshold in an animal model of neuronal migration disorder. Nat Med 15:84-90.

Matthews RT, Kelly GM, Zerillo CA, Gray G, Tiemeyer M, Hockfield S (2002) Aggrecan glycoforms contribute to the molecular heterogeneity of perineuronal nets. J Neurosci 22:7536-7547.

Milner R, Campbell IL (2002) The integrin family of cell adhesion molecules has multiple functions within the CNS. J Neurosci Res 69:286-291.

Misson JP, Edwards MA, Yamamoto M, Caviness VS Jr (1988) Identification of radial glial cells within the developing murine central nervous system: studies based upon a new immunohistochemical marker. Brain Res Dev Brain Res 44:95-108.

Miyata T, Kawaguchi A, Okano H, Ogawa M (2001) Asymmetric inheritance of radial glial fibers by cortical neurons. Neuron 31:727-741.

Morest DK (1970) A study of neurogenesis in the forebrain of opossum pouch young. Z Anat Entwicklungsgesch 130:265-305.

Morest DK, Silver J (2003) Precursors of neurons, neuroglia, and ependymal cells in the CNS: what are they? Where are they from? How do they get where they are going? Glia 43:6-18. 
Morgan JL, Dhingra A, Vardi N, Wong RO (2006) Axons and dendrites originate from neuroepithelial-like processes of retinal bipolar cells. Nat Neurosci 9:85-92.

Nadarajah B, Brunstrom JE, Grutzendler J, Wong RO, Pearlman AL (2001) Two modes of radial migration in early development of the cerebral cortex. Nat Neurosci 4:143-150.

Noctor SC, Martinez-Cerdeño V, Ivic L, Kriegstein AR (2004) Cortical neurons arise in symmetric and asymmetric division zones and migrate through specific phases. Nat Neurosci 7:136-144

Palazzo AF, Eng CH, Schlaepfer DD, Marcantonio EE, Gundersen GG (2004) Localized stabilization of microtubules by integrin- and FAKfacilitated Rho signaling. Science 303:836-839.

Pfaar H, von Holst A, Vogt Weisenhorn DM, Brodski C, Guimera J, Wurst W (2002) mPet-1, a mouse ETS-domain transcription factor, is expressed in central serotonergic neurons. Dev Genes Evol 212:43-46.

Rakic P (1971) Guidance of neurons migrating to the fetal monkey neocortex. Brain Res 33:471-476.

Ridley AJ (2001) Rho GTPases and cell migration. J Cell Sci 114:2713-2722.

Schaar BT, McConnell SK (2005) Cytoskeletal coordination during neuronal migration. Proc Natl Acad Sci U S A 102:13652-13657.

Schmechel DE, Rakic P (1979) A Golgi study of radial glial cells in developing monkey telencephalon: morphogenesis and transformation into astrocytes. Anat Embryol 156:115-152.

Scott MM, Krueger KC, Deneris ES (2005a) A differentially autoregulated Pet-1 enhancer region is a critical target of the transcriptional cascade that governs serotonin neuron development. J Neurosci 25:2628-2636.

Scott MM, Wylie CJ, Lerch JK, Murphy R, Lobur K, Herlitze S, Jiang W, Conlon RA, Strowbridge BW, Deneris ES (2005b) A genetic approach to access serotonin neurons for in vivo and in vitro studies. Proc Natl Acad Sci U S A 102:16472-16477.

Shpetner HS, Vallee RB (1989) Identification of dynamin, a novel mechanochemical enzyme that mediates interactions between microtubules. Cell 59:421-432.
Shu T, Ayala R, Nguyen MD, Xie Z, Gleeson JG, Tsai LH (2004) Ndell operates in a common pathway with LIS1 and cytoplasmic dynein to regulate cortical neuronal positioning. Neuron 44:263-277.

Snow RL, Robson JA (1995) Migration and differentiation of neurons in the retina and optic tectum of the chick. Exp Neurol 134:13-24.

Tanabe K, Takei K (2009) Dynamic instability of microtubules requires dynamin 2 and is impaired in a Charcot-Marie-Tooth mutant. J Cell Bio 185:939-948

Tanaka T, Serneo FF, Higgins C, Gambello MJ, Wynshaw-Boris A, Gleeson JG (2004) Lis1 and doublecortin function with dynein to mediate coupling of the nucleus to the centrosome in neuronal migration. J Cell Biol 165:709-721.

Thelen K, Kedar V, Panicker AK, Schmid RS, Midkiff BR, Maness PF (2002) The neural cell adhesion molecule L1 potentiates integrindependent cell migration to extracellular matrix proteins. J Neurosci 22:4918-4931.

Thompson HM, Cao H, Chen J, Euteneuer U, McNiven MA (2004) Dynamin 2 binds gamma-tubulin and participates in centrosome cohesion. Nat Cell Biol 6:335-342.

Tsai JW, Bremner KH, Vallee RB (2007) Dual subcellular roles for LIS1 and dynein in radial neuronal migration in live brain tissue. Nat Neurosci 10:970-979.

Wallace JA, Lauder JM (1983) Development of the serotonergic system in the rat embryo: an immunocytochemical study. Brain Res Bull 10:459-479.

Watanabe M, Rutishauser U, Silver J (1991) Formation of the retinal ganglion cell and optic fiber layers. J Neurobiol 22:85-96.

Xie Z, Sanada K, Samuels BA, Shih H, Tsai LH (2003) Serine 732 phosphorylation of FAK by Cdk5 is important for microtubule organization, nuclear movement, and neuronal migration. Cell 114:469-482.

Zhang Z, Galileo DS (1998) Retroviral transfer of antisense integrin alpha6 or alpha8 sequences results in laminar redistribution or clonal cell death in developing brain. J Neurosci 18:6928-6938. 